\title{
Enhanced Learning and Improved Productivity of Students' using Project Based Learning Approaches for Programming Courses
}

\author{
Shreenath Acharya ${ }^{1}$, Gayana $\mathrm{M} \mathrm{N}^{2}$ \\ ${ }^{1}$ Computer Science \& Engineering Department, St Joseph Engineering College, Mangaluru \\ ${ }^{2}$ Computer Science \& Engineering Department, St Joseph Engineering College, Mangaluru \\ ${ }^{1}$ shreenatha@sjec.ac.in \\ ${ }^{2}$ gayanam@sjec.ac.in
}

\begin{abstract}
Active learning techniques surpassed traditional teacher-centric approaches owing to their benefits of better learning from the stakeholders. The selection of a specific learning strategy varies from one course to another for productive results. Many students face difficulties in understanding programming subjects especially when it comes to applying it practically for application developments, since the curriculum permits only a certain number of specific programs to be implemented and some courses will have only theoretical subjects without a practical component. Thus, it becomes a need of the hour to make students productive in order to be confident in applying concepts learnt to the application development. The proposed method of applying a combination of project based learning involving collaborative learning will prove to be an effective platform for the students to enhance their design \& development skills. This experimentation has been applied to a total of about 420 engineering students and the average performance in the university examinations as well as their demonstration/oral presentation, viva answering skills are considered as metrics for measurement. Apart from this, students' ability to face challenges is gauged through their ability to excel in placement drives for selection to various companies. This approach has resulted in a significant improvement in students' performance in the university examinations with upto $54 \%$ of the students securing higher grades. Apart from this, it has been estimated that there is an improvement in placement rate of upto $10-15 \%$ along with increase in no. of offerings for the individual students.
\end{abstract}

Keywords: Active Learning, Project Based Learning, Performance, Application, Development

\section{Corresponding Author}

Shreenath Acharya, CSE Department

St Joseph Engg College, Mangaluru

shreenatha@sjec.ac.in

\section{Introduction}

The technological advancements have led to a drastic shift from the traditional teacher centred learning approach to the student centred approach. The task of mastering the students with new competencies and the skills to enable them enriched with higher knowledge is a must to be competitive in the current context. Thus, Project based learning would prove to be an effective tool to bridge [1] the gap between the universities educational activities and the actual needs from the industrial perspectives.

Project based learning (PBL) technique explores students' knowledge through techniques involving critical thinking and self-regulations [2]. PBL helps to engage the students in deep inquiry and in the construction of knowledge. PBL also supports collaborative learning thereby enabling better learning from the students' perspective. PBL involves the roles of the teachers to be modified as well as the environment in which they work. Teachers will be required to employ new classroom management strategies as well as scaffolding abilities to measure the effectiveness by assessing individual learning by the students. It also requires the beliefs from the teachers that their students are fully capable of learning through this approach.

PBL enables more participation from the students allowing them to acquire knowledge, skills, and personal as well as inter-personal skills. Through inquiry, students gain interdisciplinary and multi-disciplinary knowledge which builds their design thinking, problem solving, information retrieval and analysing ability [3] making them confident enough to work in any engineering team.

\section{Related Work}

G. E., Veselov et al. [1] have described that project based method is built upon a foundation of profound integration of project based practices into the traditional educational process from the first year engineering course. They have shown that using this approach, there was an increase in the students' employment status as well as the academic performance. They mentioned that this practice will also enable students to develop their own start-ups thereby becoming an entrepreneur.

Dimitra Kokotsaki et al. [4] have shown that PBL is a student-centered instruction which facilitates students' autonomy, constructive investigations, goal-setting, collaboration, communication and reflection with realworld practices. They have also mentioned that in the modern context, teacher's ability to effectively scaffold students' learning and providing guidance and support, balance between didactic instruction with in-depth inquiry 
methods and well-aligned assessment will prove to be vital to support better learning from the students.

Bart Johnson et al. [5] have implemented a mechanism in which the upper-division programs of higher semesters of engineering education were adapted into a portion of the lower semesters of engineering education at the community college. They have used Motivated Strategies for Learning Questionnaire (MSLQ) to address both motivation and learning. The specific parameters like self-efficacy, intrinsic value, cognitive strategy and self-regulation were considered to assess the effectiveness of their model.

William Brescia et al.[6] have elaborated project based service learning by providing the students with real-time critical incidents for providing solutions to the problems. Through their investigations they have shown that the PBL is an effective tool for better learning through active participation by extending their learning beyond the classroom. They have also showed that this strategy creates opportunities for students to immediately apply and provides an experiential learning for applying what they had learnt in the classroom.

Diego G Lamhar et al. [7] have implemented PBL approach on power electronics subject in order to make the students apply their theoretical knowledge into practicality. Through experimentations on design and construction of switched mode power supplies and dc-to-dc converters, they have shown that PBL approach was able to enhance students ability for task planning by being self-motivated while solving the real-time problems associated with the tasks.

Yaron Doppelt [8] has conveyed that the PBL has made a tremendous change in low- achievers by way of developing their self-responsibility in learning processes. Through experiments they have shown that this approach was able to build students' self-esteem and self-confidence thereby driving them towards success.

\section{Methodology}

The topics selected for the projects were based on the theoretical knowledge learnt in the programming subjects like Data structures with $\mathrm{C}$ and Advanced Java \& J2EE. In the Advanced java course students were given the task of database application development with appropriate front end development using the concept learnt like swings, AWT, JDBC and some other I/O programming constructs in java. In the Data structures course some sample projects were assigned to the groups for the implementation. The methodology involved in executing the process based on the number of students in the class involves sequence of steps as described below.

1. Identify the student's category: This categorization is based on their previous academic performance as well as a test conducted containing questions based on topics related to the assigned projects.

The three categories of the students identified are bright, average and weak.

2. Formation of groups: PBL technique would be more effective as it involves collaborative working within the group members. So the group formation would become a prime concern to improve the effectiveness of this approach. The formation of the group is carried out with a combination of three categories identified in the step1.

3. Number of students: It has been taken care to see that a maximum of 4 students would form a group with atleast 3 members in a group. The instructor/teacher will have a specific role to play while forming the groups.

4. Rubric formation: The rubrics are formulated by considering the specific factors like,

quality of the contents,

demonstration of the project,

presentation skills,

documentation and the report preparation,

technical skills and analysing ability and

adherence to the submission deadlines.

5. Assessment: Each individual student will be assessed for their performance; specifically for their demonstration ability, presentation skills and knowledge about the carried out project work. The grades allotted for the quality of the project, submission deadline and report are considered same for all the members of the group.

6. Feedback from the students: At the end, students will be required to fill in their learning experience through $\mathrm{PBL}$ approach in the feedback form. This feedback will provide an insight into students experience through project based learning and its effectiveness in enhancing their knowledge.

The two entities involved in the execution of the activities are the teachers and the students.

Fig. 1 shows the basic steps detailing the sequence of operations to be performed from the teacher's perspective. 


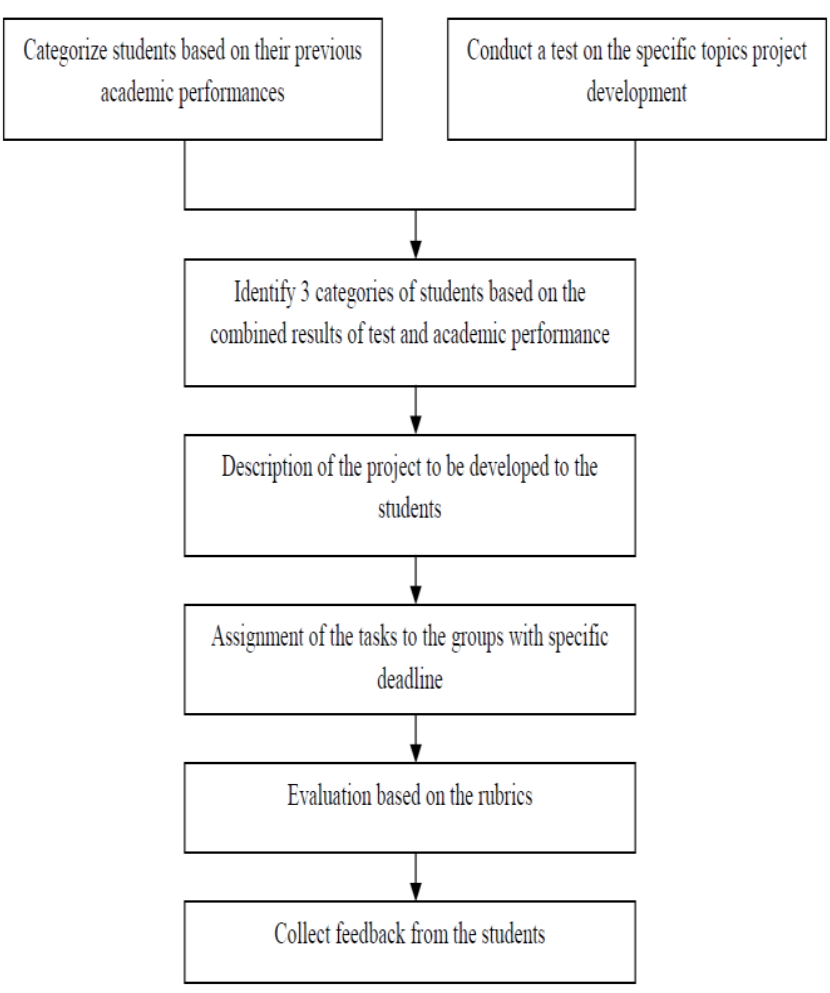

Fig.1 Sequence of steps showing teachers activities

Fig. 2 depicts the sequence of steps showing the operations to be performed by the students.

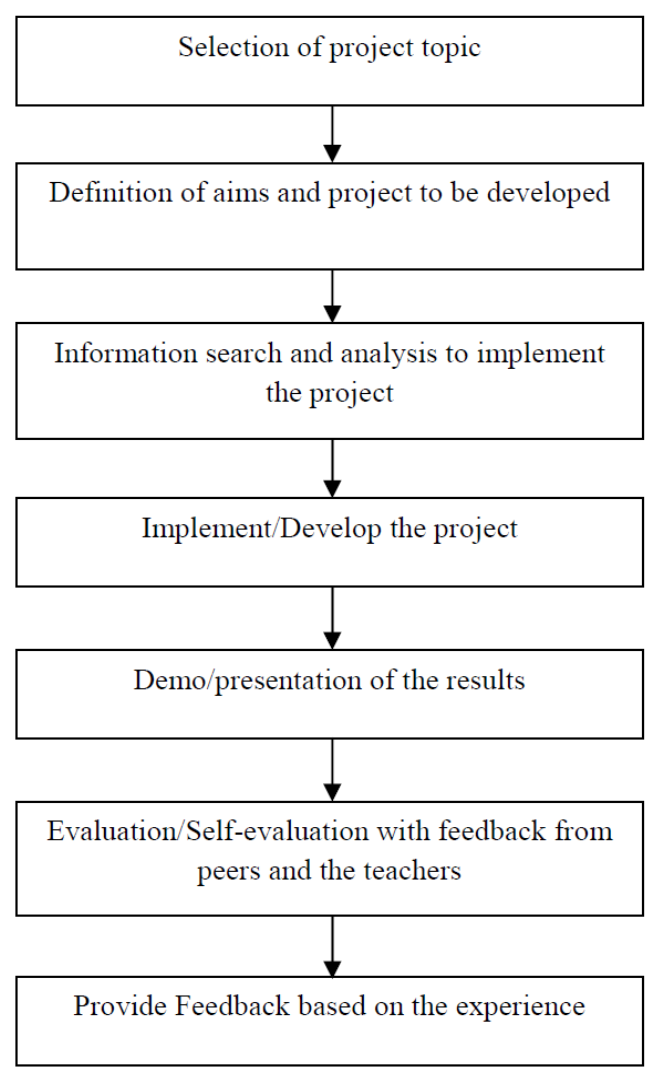

Fig. 2 Sequence of steps showing student activities

\section{Implementation}

Implementation of the activities has been considered separately for 2 programmatic subjects namely, Advanced Java \& J2EE and Data Structures and Applications.

Group selection combinations:

It was very difficult to get the similar groups formed since the numbers of students in each identified category were heterogeneous. Thus, in order to have a balanced structure, the following four types of groups namely, A, B, C and D were considered in view of betterment of overall performance of the group as shown in table 1 .

Table 1. Types of group and configurations

\begin{tabular}{|c|c|c|}
\hline $\begin{array}{c}\text { SI } \\
\text { No }\end{array}$ & $\begin{array}{c}\text { Group } \\
\text { type }\end{array}$ & Group configuration \\
\hline 1 & A & 2 Bright +1 Average +1 Weak \\
\hline 2 & B & 1 Bright +2 Average +1 Weak \\
\hline 3 & C & 2 Bright +2 Average \\
\hline 4 & D & 1 Bright +3 Average \\
\hline
\end{tabular}

A. Implementation of database based application with specific front end.

The total number of students were 96 for the Advanced Java \& J2EE course which is a professional elective for $3^{\text {rd }}$ year students. The numbers of groups formed were 24 as per the configurations shown in the Table1.

Topic: Design and demonstrate a Java based Database application with a suitable front end using string handling methods.

Description:

1. Each member needs to demonstrate the working of the project and answer the queries related to developed work.

2. Use open source Java Editors like NetBeans/Eclipse and Databases like Oracle, MySql etc....

3. Design front end using Swings/AWT, use string manipulation functions also in the front end to demonstrate their significance as appropriate.

4. Submit a report containing the Introduction, Objectives, Hardware and Software requirements, Working code, Snapshots (output) of the results along with the References at the end.

Students were given a choice to identify a suitable unique topic for their project development. The information related to the selected topic, state of the art, software and hardware requirements, the details of the implementation and 
reporting purposes were given as the responsibility for the respective group members.

The concepts related to the string handling using java for implementing the functionalities were presented using a flipped classroom approach. The students were asked to watch the videos posted in the Google classroom. The assessment of the same was included as a part of the test conducted for the group formation.

Evaluation: The developed projects were evaluated based on the rubrics specifying the parameters shown in the Table 2.

Table 2: Assessment Rubrics for Database Application Project

\begin{tabular}{|c|l|l|l|l|}
\hline Topic & \multicolumn{1}{|c|}{$\begin{array}{c}\text { Poor } \\
1\end{array}$} & \multicolumn{1}{|c|}{$\begin{array}{c}\text { Average } \\
2\end{array}$} & \multicolumn{1}{|c|}{$\begin{array}{c}\text { Good } \\
3\end{array}$} & \multicolumn{1}{|c|}{$\begin{array}{c}\text { Excellent } \\
4\end{array}$} \\
\hline $\begin{array}{c}\text { Submission } \\
\text { (2) }\end{array}$ & $\begin{array}{l}\text { Missed the due date } \\
\text { by more than one } \\
\text { day }\end{array}$ & $\begin{array}{l}\text { Posted assignment } \\
\text { after one day }\end{array}$ & $\begin{array}{l}\text { Posted the } \\
\text { assignment by due } \\
\text { date }\end{array}$ & $\begin{array}{l}\text { Posted the } \\
\text { assignment before } \\
\text { due date }\end{array}$ \\
\hline Quality & $\begin{array}{l}\text { Application } \\
\text { developed contains } \\
\text { very few features }\end{array}$ & $\begin{array}{l}\text { Application } \\
\text { developed } \\
\text { contains few } \\
\text { features }\end{array}$ & $\begin{array}{l}\text { Application } \\
\text { developed } \\
\text { contains most of } \\
\text { the required } \\
\text { features and } \\
\text { useful }\end{array}$ & $\begin{array}{l}\text { Application } \\
\text { developed } \\
\text { contains all the } \\
\text { required features } \\
\text { and useful }\end{array}$ \\
\hline $\begin{array}{c}\text { Demo \& QA } \\
\text { (3.5) }\end{array}$ & $\begin{array}{l}\text { Students have no } \\
\text { clear idea about } \\
\text { implementation, } \\
\text { Answers provided } \\
\text { are not correct }\end{array}$ & $\begin{array}{l}\text { Demonstration is } \\
\text { satisfactory, not } \\
\text { able } \\
\text { toprovideanswer } \\
\text { to all the } \\
\text { questions }\end{array}$ & $\begin{array}{l}\text { Demonstration } \\
\text { was clear, } \\
\text { Answers provided } \\
\text { are correct but not } \\
\text { very accurate }\end{array}$ & $\begin{array}{l}\text { Clear } \\
\text { Demonstration } \\
\text { and answers } \\
\text { provided are } \\
\text { correct and } \\
\text { accurate }\end{array}$ \\
\hline $\begin{array}{c}\text { Report } \\
\text { (3) }\end{array}$ & $\begin{array}{l}\text { Not properly } \\
\text { documented/Format } \\
\text { ted }\end{array}$ & $\begin{array}{l}\text { Minimal } \\
\text { documentation }\end{array}$ & $\begin{array}{l}\text { Documentation } \\
\text { does not meet the } \\
\text { expectation fully }\end{array}$ & $\begin{array}{l}\text { Excellent } \\
\text { Documentation }\end{array}$ \\
\hline
\end{tabular}

B. Implementation of Data structure based application using $\mathrm{C}$ programming.

The total numbers of students were 118 for the Data Structures and Applications course which is a core subject for the $2^{\text {nd }}$ year students. The numbers of groups formed were 29 as per the configurations shown in the Table1. The assigned projects were specifically meant for providing an opportunity to apply the theoretical concepts into implementation. This would provide them a platform for better understanding of the concepts learnt and also boosts their confidence to demonstrate it in an effective manner.

\section{Topic: Application of data structures}

1. Team formation:

- A team of maximum four members.

- In batches where all teams cannot be of size four because of the size of the batch, a few teams may be formed (only in such batches) of size 3

- No team size shall be less than 3 or greater than 4

2. Each team shall submit a report on the mini project in line with the format provided.
A sample of some of the assigned projects for implementation is shown in the Table 3.

3. Evaluation: The developed mini projects were evaluated based on the rubrics shown in the Table 4.

Table 3: Sample projects assigned to the students

\begin{tabular}{|c|l|}
\hline SI No & \multicolumn{1}{|c|}{ Topic name } \\
\hline 1. & Library Management System \\
\hline 2. & Online Shopping \\
\hline 3. & Online Movie Ticket Booking \\
\hline 4. & Food Management \\
\hline 5. & Maze Problem \\
\hline 6. & Tic Tac Toe Game \\
\hline 7. & Hangman Game \\
\hline 8. & Undo / Redo Using Stack \\
\hline 9. & Dictionary Implementation \\
\hline 10. & Customer Account Bank \\
\hline 11. & Sanagement System \\
\hline 12. & Parking Management System \\
\hline 13. & Priority Based Reminder \\
\hline 14. & Calendar Application \\
\hline 15. & Hotel Management \\
\hline 16. & Phonebook Application \\
\hline 17. & Quiz Game \\
\hline &
\end{tabular}

Table 4: Assessment Rubrics for Application of Data structures

\begin{tabular}{|c|c|c|c|c|c|}
\hline Criteria & Barely Acceptable(1) & Basic(2) & Arerage(3) & $\operatorname{ood}(4)$ & Excep \\
\hline $\begin{array}{c}\text { Completion of } \\
\text { project and } \\
\text { demonstration (3) }\end{array}$ & $\begin{array}{l}\text { Partial Completion } \\
(0-24 \%)\end{array}$ & $\begin{array}{l}\text { Partial Completion } \\
(25-50 \%)\end{array}$ & $\begin{array}{l}\text { Partial Completion } \\
(51-64 \%)\end{array}$ & $\begin{array}{l}\text { Partial Completion } \\
(65 \%-89 \% \%)\end{array}$ & Complete \\
\hline Report (3) & $\begin{array}{l}\text { Incomplete phases, } \\
\text { missing index, page } \\
\text { numbers, inconsistent with } \\
\text { format prorided }\end{array}$ & $\begin{array}{l}\text { Phases r partially } \\
\text { completer } r \text { and } \\
\text { inconsistent with the } \\
\text { format given }\end{array}$ & $\begin{array}{l}\text { Phases almost } \\
\text { complete but repoot } \\
\text { is inconsistent with } \\
\text { the format provided }\end{array}$ & $\begin{array}{l}\text { Phases almost } \\
\text { complete and almost } \\
\text { consistent with } \\
\text { format prorided with } \\
\text { few inconsistencies }\end{array}$ & $\begin{array}{l}\text { Phases complete and } \\
\text { consistent with } \\
\text { format prorided }\end{array}$ \\
\hline $\begin{array}{l}\text { Submission on time } \\
\text { (1) }\end{array}$ & $\begin{array}{l}\text { Submission } \\
\text { after the due }\end{array}$ & $\begin{array}{l}\text { Submission on four } \\
\text { or more days after } \\
\text { the due date }\end{array}$ & $\begin{array}{l}\text { Submission on two } \\
\text { of more days after } \\
\text { the due date }\end{array}$ & $\begin{array}{l}\text { Submission on very } \\
\text { next day of the due } \\
\text { date }\end{array}$ & $\begin{array}{l}\text { Submission on or } \\
\text { before the due date }\end{array}$ \\
\hline
\end{tabular}

\section{Results}

The outcome of the PBL activity conducted on the two courses and their reflections on the university examinations have been considered for assessing its effectiveness. The metrics like students scoring distinction and other category of students who have cleared the subjects in the corresponding semester of the academic year are taken into consideration to plot the graph.

A. Development of the Database application using Adv. Java. 
The results of three academic years were considered to evaluate the effectiveness of the approach. The 3 academic years 2015-16, 2016-17 and 2017-18 have been considered for the comparison. Among these, in 2015-16, there were no use of PBL strategy in the teaching-learning strategy, in 2016-17, the implementation of PBL strategy began and in 2017-18, PBL was implemented in a strategic manner. 2018-19 year is not considered since this course is in $3^{\text {rd }}$ year of the Engineering course and the students will be studying it in the current academic year.

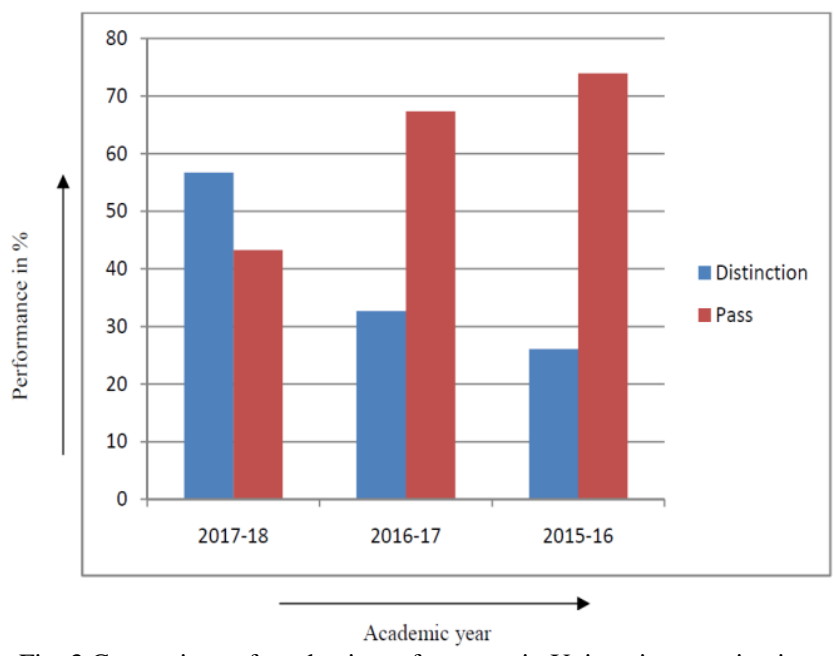

Fig. 3 Comparison of academic performance in University examination

Fig.3 clearly depicts an improved performance from the students enrolled in the academic years 2017-18 and 201617 compared to the performance from the enrolled students in 2015-16. It has been estimated that the performance boost was about $37.5 \%$ in $2017-18$ and $12.3 \%$ in $2016-17$ compared to the performance in 2015-16. This performance boost in terms of the higher scores clearly indicates the effectiveness of the PBL approach in this course.

B. Data structure based application development using $\mathrm{C}$ programming

The results of four academic years were considered to evaluate the effectiveness of the approach. The four academic years 2015-16, 2016-17, 2017-18 and 2018-19 have been considered for the comparison. Among these, in 2015-16, there were no use of PBL strategy in the teachinglearning process, in 2016-17, the implementation of PBL strategy began and in 2017-18 and 2018-19, PBL was implemented in a productive manner.

Fig. 4 clearly shows the effectiveness of the project based learning strategy in terms of performance improvement of students in the university examinations. It has been estimated that there was an improvement of $28.81 \%, 32.25 \%$ and $14.28 \%$ respectively in the students' performance compared with the students enrolled in 2015-16.
The effect of the PBL strategy on the placement statistics have been depicted by considering the factors like number of successfully placed students and the total number of offers in an academic year. The placements of the past four years have been considered for the comparison. They are, 2019-20, 2018-19, 2017-18 and 2016-17 respectively.

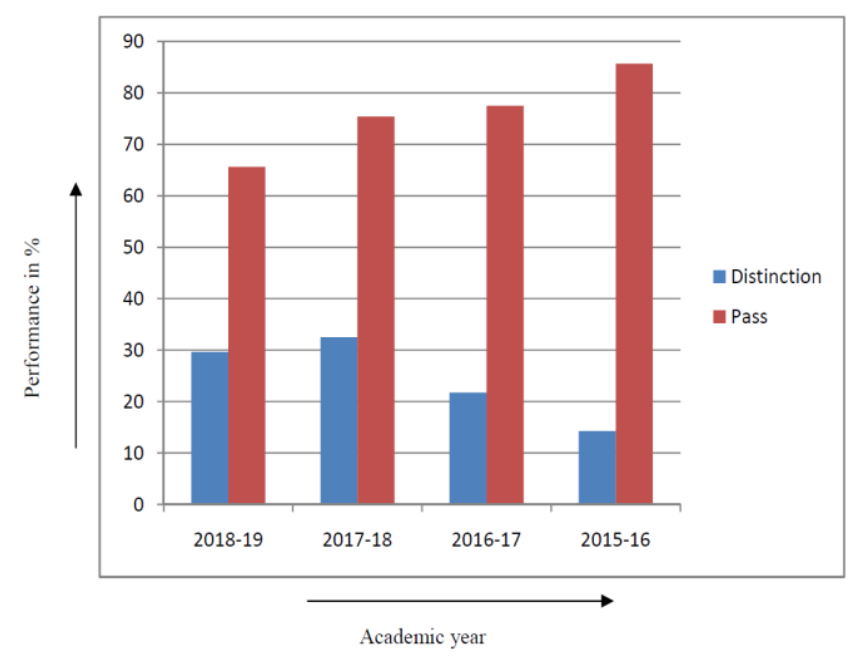

Fig. 4 Comparison of academic performance in University examinations

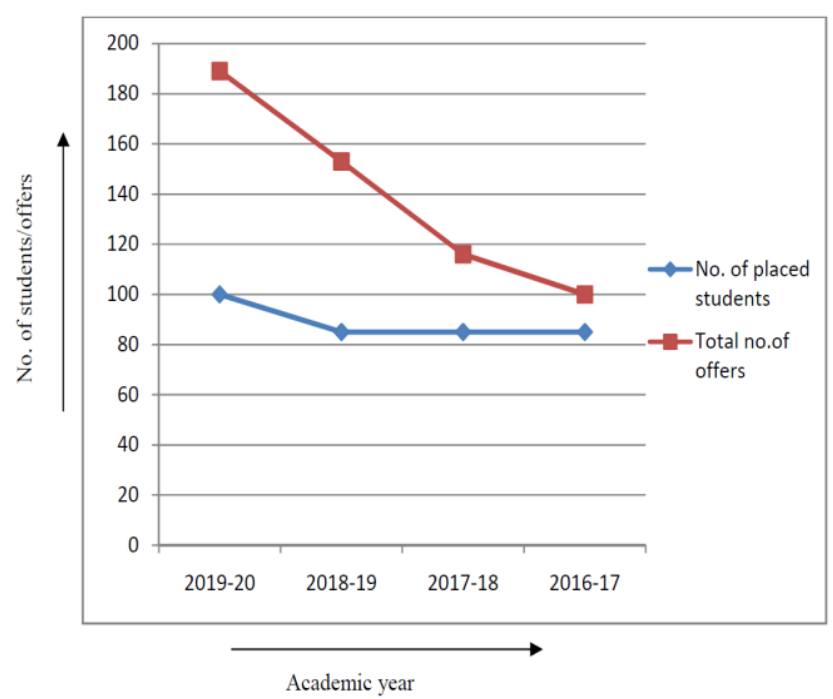

Fig. 5 Comparison of placement statistics

Fig. 5 clearly indicates that number of students placed is higher in 2019-20 compared with the previous academic years. These students were enrolled in 2016-17 and have got an exposure into using active learning strategies like Project based learning during their study of the programming courses. It can also be seen that there is a drastic increase in the number of offers in 2019-20.

It was also found that in the academic year 2019-20, 2 students had 5 offers, 5 students had 4 offers, 14 students had 3 offers and also 38 students had 2 offers apart from students with single offers clearly depicting the students' 
motivation, confidence and the ability to excel in their chosen fields.

The feedback received from the students about the PBL activity based on the following questions is depicted in the Fig. 6.
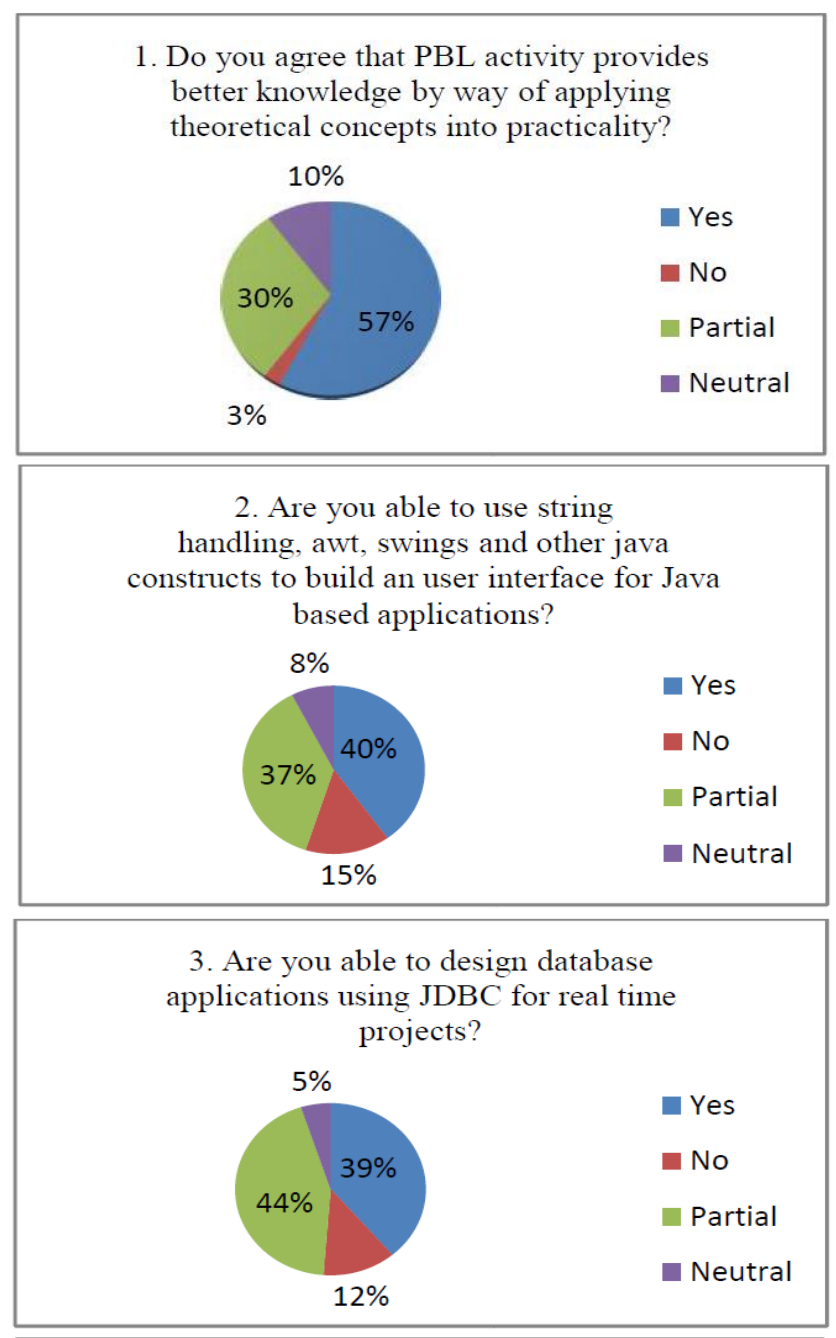

4. Do you agree that you have achieved the ability to work in teams and collaboratively contribute to the overall completion of the project?

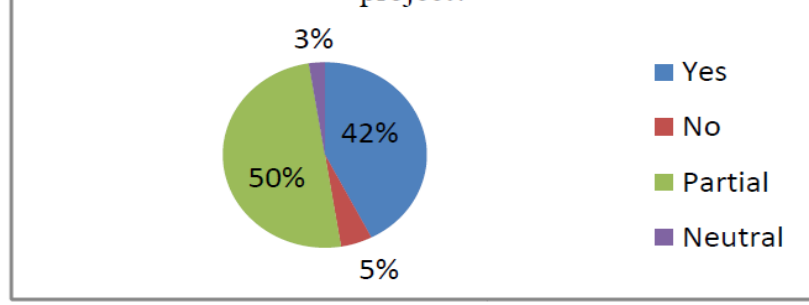

Fig. 6 Students feedback

5. Any suggestions/comments for improvement

The main concerns from the students are:

1. Insufficient time for project completion: The allotted time for the project completion was 1 month. Some of the students felt that it was not sufficient to complete the whole project with its documentation.

2. Some of the students expressed their difficulty to work with heterogeneous team members having different levels of learning abilities.

Similarly, the feedbacks forms were shared with the students for data structure applications projects. As a whole $75-80 \%$ felt that the PBL activity has helped them to improve their learning skill as well as boosted their confidence level.

\section{Conclusion}

The active learning approach using project based learning has been effectively applied on two programming subjects: data structures using $\mathrm{C}$ programming and advanced java. Based on the obtained results in comparison with teaching learning activities without using PBL approach has showed an improved performance upto $37.5 \%$ in advanced java programming and upto $32.25 \%$ in data structures with applications. It has also proven an increase in the placement opportunities by way of number of students getting placed as well as individual offers for the students.

This approach along with some other best learning practices could be extended to a large scale by promoting inter-disciplinary projects and making it as a part of assessments from the first year itself. The complexity of the projects can be increased when they move to $2^{\text {nd }}$ and $3^{\text {rd }}$ years so that they will be poised to build start -ups and also can easily get through with placement drives.

\section{Acknowledgement}

We would like to thank the management of St Joseph Engineering College, Mangaluru for supporting and providing opportunities to implement active learning strategies to enhance the productivity of teaching learning process.

\section{References}

Veselov, G. E., Pljonkin, A. P. and Fedotova, A. Y (2019), Project-based learning as an effective method in education, Conference paper doi:10.1145/3341042.3341046

Quint, J and Condliff, B(2018), Project-Based Learning A Promising approach to improving student outcomes, MDRC article - Building knowledge to improve social policy.

Frank, M., Lavy, I. and Elata, D.(2003) Implementing the Project based learning approach in an academic engineering course, International Journal of Technology and Design Education, 13, 273-288

Kokotsaki, D., Menzies, V., and Wiggins, A.(2016) Project-based learning: A review of the literature, Research Article. https://doi.org/10.1177/1365480216659733 
Johnson, B., Ulseth, R., Smith, C., and Fox, D., (2015), The Impacts of Project Based Learning on Self-Directed Learning and Professional Skill Attainment, IEEE

Bresica, W., Mullins, C., and Miller, M., (2009), Projectbased Service-Learning in an Instructional Technology Graduate Program, International Journal for the Scholarship of Teaching and Learning, Volume 3, Number 2, Article 20.

Lamar,G., D., Miaja, P.,F., Arias, M., Rodríguez, A.,(2012), Experiences in the Application of Project-Based Learning in a Switched-Mode Power Supplies Course, IEEE Transactions on Education, VOL. 55, NO. 1

Dopplet, Y.,(2003), Implementation and Assessment of Project-Based Learning in a Flexible Environment, International Journal of Technology and Design Education, 13, 255-272, Kluwer Academic Publishers. 